\title{
Developing the Next Generation of Entrepreneurs: Giving Students the Opportunity to Gain Experience and Thrive
}

\author{
Robin Bell (r.bell@worc.ac.uk) \\ International Journal of Management Education (2015), Vol. 13, No. 1, pp. 37-47. \\ http://doi.org/10.1016/i.ijme.2014.12.002
}

\begin{abstract}
Higher Education Institutions (HEls) have increasingly utilized experiential approaches in business education; however, some researchers have suggested that further research is required to investigate the effectiveness and student reaction to such approaches. The aim of this study is to determine the impact of an experiential learning approach on the perceived development of entrepreneurial traits and to measure the level of both student engagement and satisfaction. The approach was designed and tested during a Higher National Diploma (HND) entrepreneurship module in a British HEl. Traditional taught sessions were blended with applied activities that required students to utilize the skills they learned to complete steps of the activities, which increased in length and complexity. Results found both a high level of student satisfaction and engagement and the belief that the module's experiential approach had, in many instances, helped to develop entrepreneurial traits. Successful practice and modifications are discussed.
\end{abstract}

\section{Keywords}

Entrepreneurship Education, Experiential Learning, Entrepreneurial Traits 


\section{Introduction}

Within the last two decades, higher education has seen considerable growth in both the development of entrepreneurship as a subject and in the number of entrepreneurship courses offered. Entrepreneurship courses are mainly found in business schools within higher education institutions (HEIs) (Collins et al., 2006), and are often taught alongside traditional business disciplines, including management, marketing and finance. Entrepreneurship education can be defined as the development of attitudes, behaviours, and capabilities that can be applied during an individual's career as an entrepreneur (Wilson, 2008). However, entrepreneurship is a complex phenomenon that requires decision making across all aspects of business activity in situations where there are high levels of uncertainty in a global and dynamic socio-technical context (Timmons et al., 2011). This has led to considerable debate in the literature regarding the most appropriate teaching methods to develop entrepreneurial knowledge and stimulate learning (Balan and Metcalfe, 2012). Past research has suggested that the success of entrepreneurship education has been mixed, with some research reporting positive outcomes (e.g. Fayolle et al., 2006; Athayde, 2009; Karlsson and Moberg, 2012), and other research reporting less favorable outcomes (e.g. von Graevenitz et al., 2010: Oosterbeek et al., 2010). The lack of consistency in the findings may be due, in part, to methodological weaknesses. It may also be attributed to a general lack of agreement on a conceptual model for the analysis of entrepreneurial education (von Graevenitz et al., 2010).

Academic support has been increasing for the use of non-traditional higher education learning environments in the study of entrepreneurship (Gibb, 2002; Jones and English, 2004). As a result, many entrepreneurship educators have adopted approaches based on Kolb's experiential learning cycle (Kolb, 1984), which draws on earlier works that emphasize the central role experience plays in learning and development (Dewey, 1963; Piaget, 1950) to develop a dynamic, holistic model of an experience-based learning process (Kolb and Kolb, 2009). This approach departs from traditional lecturer-led passive learning, increasing the emphasis on action-orientated or active experiential learning, problem solving, project-based learning and peer evaluation. This has led to a wide range of new active and creative problem solving and learning by doing experiential approaches being adopted. New approaches have included business simulations, meeting and interviewing entrepreneurs, developing business plans, and attending entrepreneurship forums. Piercy (2013) argues however, that while experiential approaches have become an increasingly favoured form of pedagogy for business educators, student reactions to experiential approaches require further investigation. 
The qualitative research herein builds on previous research by exploring how experiential learning in an applied setting supports the development of four key entrepreneurial behaviours or characteristics. The teaching approach required participants to be actively involved in planning, developing, and implementing two student-led events. The students then reported via reflective essays on how, and whether, the four key behaviours had been utilised, and how they could have been used and developed further. Additional qualitative feedback was collected through a series of interviews. Finally, students' module evaluations were analysed to discern student satisfaction with these experiential approaches.

\section{Literature Review}

\section{Active and Experiential Learning}

The development of students' critical thinking skills is one of the main goals of higher education. This encourages the movement beyond knowledge comprehension and towards the higher order skills of analysis, synthesis and evaluation (Bloom et al., 1956). The core elements of active learning are student activity and student engagement in the learning process, in contrast to traditional lecture formats where content is passively transmitted from the lecturer to the students (Prince, 2004). In this process, active learning should involve the use of the higher order thinking skills of analysis, synthesis and evaluation. In the past, it has been argued that higher education institutions have done little to foster active learning aimed at developing the critical thinking and creativity of business students. As a result, corporations have reported that entry-level graduates have been lacking in these skills (Snyder, 2003).

Business schools have increased their focus on developing the skills required for business, marketing and entrepreneurship, and instructors are exploring new and inventive ways to introduce active and experiential approaches that can help to prepare students for their future careers. Experiential learning can be described as a participatory form of learning that involves participants in using a range of mental processes to synthesize information in an active and immersive environment (Feinstein et al., 2002).

Kolb (1984 p6) described the importance of participants being "able to involve themselves fully, openly, and without bias in new experiences; they must be able to observe and reflect on these experiences from many perspectives; they must be able to create concepts that integrate their 
observations into logically sound theories; and they must be able to use these theories to make decisions and solve problems".

Experiential Learning Theory has had a major impact on both the design and delivery of educational programs in management training and development, and formal management education (Kolb and Kolb, 2009). Many business school educators have accordingly adopted approaches based on Kolb's (1984) experiential learning cycle to develop a dynamic, holistic model of an experience-based learning process. It is a process through which knowledge is created through the transformation of experience (Kolb, 1984 p 41), and as such involves an active interpretation of experience. Reflection is an important element in this approach and structured approaches to the reflective stage can enhance this process (Platzer et al., 1997).

As academic literature has increasingly recognized the value of non-traditional higher education learning environments (emphasizing action-orientated experiential learning), new approaches have been introduced within the HEI system to reap the benefits of experiential learning. It has been argued that such active learning approaches address many of traditional teaching approaches' limitations (Ruben, 1999; Lean et al., 2006; Caldwell, 2007; Knight and Wood, 2005; Makienko and Bernard, 2012; Mahajan, 2012), and generally result in improved knowledge retention, increased problem solving skills and increased motivation for future learning (Snyder, 2003; Rhem, 1998; Bonwell and Elson, 1991). Importantly, it has been argued that whilst lectures are a useful vehicle for imparting knowledge, they do not lead to thought or attitude adjustment and the development of behavioural skills or inspire interest in the subject (Grimley et al., 2011). However, active engagement in an activity together with enjoyment of the experience can significantly increase both motivation and learning (Karns, 2005; Elam and Spotts, 2004). It is, perhaps, not surprising that active experiential learning approaches are increasingly being introduced into syllabi to supplement traditional teaching formats (Piercy, 2013; Karns, 2005; Daly, 2001). While studies on student satisfaction with experiential learning are varied, Piercy and Caldwell (2011) found, in a multicultural study, that students reported high levels of satisfaction with experiential learning.

\section{Working within Groups}

Working within groups on a project provides a forum for experiential learning, enabling a studentcentred focus in the classroom that creates an active learning experience (Patel, 2003). A cooperative learning experience can enhance student success by enabling students to share understanding and support one another. It may increase student motivation, as students may feel a 
sense of accountability (Ormrod, 2008). Tsay and Brady (2012) found that involvement in cooperative learning is a positive predictor of academic performance. Johnson and Johnson (1986) found that students involved in cooperative learning retained information for longer and achieved higher levels of thought than their peers who worked alone. Students have also been shown to develop their higher-order critical thinking skills as a result of cooperative learning (Gokhale, 1995).

\section{Entrepreneurial Education}

It is now generally accepted that entrepreneurship, or at least certain facets of it, can be taught and that entrepreneurship is not limited only to those who are born with certain skills, characteristics and attributes (Kuratko, 2005; Robinson et al., 1991; Drucker, 1985). Entrepreneurship is often taught in business schools alongside traditional management disciplines. As a result, educators may use different teaching approaches that are based on the learning objectives and the requirements of students (Van der Sijde, 2008).

Traditional management education can be regarded as being positivistic in nature whilst the entrepreneurial process requires a plethora of skills and is idiosyncratic in its nature (Jack and Anderson, 1999). The entrepreneurial process involves the creation of something, often using new processes or techniques, in order to extract value (Schumpeter, 1942). It is based on opportunity recognition and is necessarily an inductive process, usually involving varying degrees of risk and uncertainty (Jack and Anderson, 1999). This type of education and learning requires exposure to and engagement in the often complex stages of the entrepreneurial process, which requires a different learning environment within the higher education setting (Gibb, 2002; Jones and English, 2004). This involves a departure from traditional lecturer-led passive learning towards an increased emphasis on action-orientated, experiential learning, problem solving, project-based learning and peer evaluation. Zahra and Welter (2008 p.188) have argued, "Entrepreneurial skills are learned in a variety of ways and methods. Some entrepreneurial skills are best learnt by doing and observing others. Whilst lecture based education has its place in the curriculum, the training of future entrepreneurs should also include interactive and action orientated methods."

It has been argued that entrepreneurship education can develop new entrepreneurial skills by including real-life experiences (Arvanites et al., 2006). Jones and Iredale (2010) suggested that entrepreneurship education requires experiential learning styles, creative problem solving and learning by doing in order to engage students. This approach departs from the traditional lecturerled passive learning, towards a greater emphasis on action-orientated, experiential learning, problem solving, and project-based learning style of teaching (Jones and English 2004). Support has 
also been expressed for action-orientated learning by doing activities in group or network contexts (Rasmussen and Sorheim, 2006), and for student led approaches (Fiet, 2001). Some educators have argued for the implementation of experiential approaches such as meeting and interviewing entrepreneurs, developing business plans, and attending entrepreneurship forums (Sherman et al., 2008), computer simulations, business visits, and relevant and realistic class exercises (Soloman, 2008). Other approaches have included social enterprise placements, case study workshops (Bevan and Kipka, 2012), and involvement in business consulting initiatives (Hynes and Richardson, 2007). Bevan and Kipka (2012) suggest that the most commonly adopted experiential learning formats in business schools include team building exercises, simulations, guest speakers and internships.

\section{Key Entrepreneurial Characteristics}

Entrepreneurial education can be viewed broadly in terms of both the skills that can be taught and in the characteristics that can be encouraged and developed in individuals (Jones and English, 2004). Three of the most widely studied and discussed entrepreneurial behaviours or characteristics in the entrepreneurship literature are those of innovativeness, the willingness to take risks, and proactiveness (e.g. Wiklund, 1999; Lumpkin and Dess, 1996; Covin and Slevin, 1989). Based on Miller's (1983) conceptualisation, these three dimensions have been identified and used consistently as a measure of the 'entrepreneurial orientation' of organisations (Rauch et al., 2009), which has emerged as a major construct within the strategic management and entrepreneurship literature over the last twenty years (Tang et al., 2008). Developed into a measurement instrument by Covin and Slevin (1989), to measure the entrepreneurial orientation of organisations, these behaviours have more recently been used to measure entrepreneurial orientation at an academic level (e.g. Bolton and Lane, 2012: Taatila and Down, 2012). Bolton and Lane (2012) developed a measurement instrument based on these three dimensions to measure the entrepreneurial orientation of individual university students, which was found to correlate with entrepreneurial intention. This research will focus on these three characteristics, together with the degree of selfefficacy/esteem/confidence of individual students. The self- efficacy construct has played an important part in in entrepreneur motivation research (Pruett et al., 2009) and has been widely studied as an entrepreneurial behavioural trait in both professionals and students (e.g. Gibson and Harris 2009; Pruett et al., 2009; Harris et al., 2007; Gelderen et al., 2008; Florin et al., 2007; Louw et al., 2003; Robinson et al., 1991). There is also much empirical evidence of the connection between perceived self-efficacy and entrepreneurial intentions (Pruett et al., 2009; Sesen, 2013: Zhao et al., 2005). The four characteristics that will be used in this research are now considered briefly. 


\section{Innovativeness}

Innovation is a constant theme within entrepreneurship literature (Drucker, 1985; Lumpkin and Dess, 1996; Miller, 1983). Lumpkin and Dess (2001) defined innovation in terms of developing and introducing new products and services, whilst Robinson et al. (1991) considered it in terms of perceiving and acting upon activities in new and unique ways. Innovation often involves creation or creative destruction (Schumpeter, 1942). Drucker (1985) argued that innovation and entrepreneurship go hand in hand. Gundrya, Ofsteinb, and Kickulc (2014) suggested that the development of increased perceived creativity during an entrepreneurship module could result in a transfer of innovative skills to the workplace.

\section{Proactiveness}

The proactive nature of entrepreneurs has been highlighted by many researchers including Covin and Slevin (1989), Lumpkin and Dess (1996), Miller (1983), and Naman and Slevin (1993). Proactiveness can be considered as the opposite of reactiveness and focuses on implementation and on making things happen, using any means necessary (Davis et al., 1991). It may involve opportunity seeking, forward looking and anticipating the future actions of competitors (Lumpkin and Dess, 2001). Crant (2000) defined proactive behaviour as an individual's initiative to improve on or to create entirely new circumstances.

\section{Risk Taking}

It has been argued that risk is inherently embodied in the practice of entrepreneurship; the creation of new ventures is inherently a risk-laden process (Aldrich and Martinez, 2007). Evidence that entrepreneurs have a more positive attitude towards risk than non-entrepreneurs has been found by many researchers, including Stewart and Roth (2004), Begley and Boyd (1987), Carland et al. (1995), and Stewart et al. (1999). Davis et al. (1991) highlighted that entrepreneurship involves a balance of the associated risks involved and an attempt to manage those risks. Denslow and Giunipero (2003) have argued that entrepreneurs are prepared to take calculated risks and can make decisions based on limited information, as they possess an on-going desire to set and obtain increasingly challenging goals. In a business setting, entrepreneurs are generally perceived as more open to risk than managers (Masters and Meier, 1988) because entrepreneurs bear the ultimate responsibility for the decision (Gasse, 1982). 


\section{Self-Efficacy}

Self-efficacy (also referred to as self-confidence and self-esteem) is a belief in one's ability to successfully complete a task or attain a desired goal, and as such, is a useful construct to predict an entrepreneur's behavioural choice, level of persistence, and overall effectiveness (Chen et al., 1998). It has been argued that differences in work interest and performance can often be linked to differences in self-efficacy, which affects individual persistence, initiative and performance (Krueger, 2000). Entrepreneurial self-efficacy has been widely researched as one of the personality traits that motivates entrepreneurial behaviour (Chen et al., 1998; De Pillis and Reardon, 2007; Karlsson and Moberg, 2012), and enables entrepreneurs to recognize opportunities, manage resources, and juggle the challenges of enterprise management (Kumar, 2007; Shane et al. 2003; Wilson et al., 2007). There is also empirical evidence showing a connection between perceived self-efficacy and entrepreneurial intentions (Zhao et al., 2005).

\section{Research Aim}

HEIs have increasingly utilized experiential approaches in business education; however, Piercy (2013) has suggested that further research is required to investigate the effectiveness and student reaction to experiential learning approaches. This paper investigates how experiential learning in an applied setting can aid the development of four key entrepreneurial behaviours identified above. The research identifies successful practice and seeks to explore how the approaches used in the study could be adjusted to improve students learning. Finally, this research seeks to measure the level of both student engagement and satisfaction.

\section{The Course and Methodology}

\section{The Course/Module}

A new entrepreneurship Higher National Diploma (HND) module was set up at a UK HEI to provide applied 'scaffolded' activities that increased in length and complexity. Twenty-nine students registered for the module, which was conducted over the course of one academic year. The module's taught content consisted of twenty weekly sessions. During the first third of each session, the instructor presented the week's topics and discussed how the topic applied to their group activity. After this, the students applied the day's lesson in small groups, which they organized themselves, as they worked towards the module's two applied activities. The information was thus presented in bite-sized pieces, with ample time for students to reflect and apply what they had just learned within peer groups. Guidance was available from the instructor, as needed. As the semester 
progressed, students were given greater autonomy and less guidance as they developed their entrepreneurial skills. Structured reflection was built into the applied activities to help students question, make sense of, and come to a better understanding of what had taken place (Ross, 2011; Platzer et al., 1997; Mezirow, 1990). In short, the module provided the basic knowledge about entrepreneurial skills via traditional lectures, experiential opportunities to set up and run a venture, and post-activity reflection on the decisions made and actions taken, allowing learners to identify the areas of strength and weakness, as well as developments made through the module.

\section{Applied Activity 1: Pop-up Shop}

Students were assigned the task of organizing a pop-up shop in the city's main shopping centre. The instructor gave students the objective of using the shop to promote the University facilities, focusing on its aspects that could be enjoyed by the public, e.g., the library, sports teams, and museum. Students organized themselves in groups of five, planned their event, and set performance objectives. Each group identified the resources they would need for their shop, with the instructor providing suggestions. After the pop-up shops, students reflected on the activity and made presentations to their classmates outlining their successes, changes they made during the event, and what they would have done differently.

\section{Applied Activity 2: Social Event}

Students organized and managed a theme-night event for university students. Less structure was provided for this activity, and students groups were challenged to apply their learning to make their event profitable. For example, groups performed market research during the design phase of their enterprise. The groups composed individual business plans that detailed the management, marketing, and financing of the theme night. They then worked with the instructor to procure resources and with the venue manager to coordinate logistics. Groups carried out their events on consecutive Monday nights at the HEI Student Union.

\section{Student Assessment}

Students were assessed at three stages of the module. The first assessment was the group presentation following the pop-up shop. For the second assessment, the instructor evaluated the business plans students developed for the social event for suitability and professionalism, as well as its enactment. Students wrote an essay for the third assessment in which they critically reflected on the module and discussed how the taught content and the applied activities developed their entrepreneurial traits and behaviours. Entrepreneurial behaviours and traits were discussed 
throughout the module and students were thus prepared to reflect on these by the time they composed their essays. In addition, they were asked what changes could be introduced to make the experiential learning more effective in developing the entrepreneurial traits. Feedback was available throughout the module and after each assessment.

The planned learning and teaching activities and assessments were aligned with the intended learning outcomes, in line with Biggs' (1996) work on constructive alignment. The activities and assessments were thus designed to enable students to construct their own learning. A breakdown of the intended learning outcomes and the module assessments are displayed in table 1.

Table 1: Intended Learning Outcomes \& Module Assessments

\section{Intended Learning Outcomes}

To be able to:

1. Understand and apply market research in the formulation of a business venture idea.

2. Assess the key resources and capabilities required to launch a new venture.

3. Demonstrate effective presentation skills and business plan development.

4. Understand and apply entrepreneurial skills to the development and enactment of a new venture.

5. Identify and critically analyse the application and development of entrepreneurial skills.

\section{Summative Module Assessment}

Intended Learning

Outcome Assessed

$\begin{array}{ccc}\text { Assignment 1 - Pop-Up Shop } & \begin{array}{c}\text { Pop-up shop reflection presentation } \\ \text { Development of a business plan for }\end{array} & 2,3 \\ \text { Assignment 2-Social Event } & \begin{array}{c}\text { the proposed event; Enactment of } \\ \text { the proposed event }\end{array} & 1,2,3,4 \\ \text { Assignment 3 - Critical } & \begin{array}{c}\text { Critical reflective analysis of } \\ \text { Reflection }\end{array} & \text { entrepreneurial skill development }\end{array}$

\section{Methodology}

The reflective essays students composed at the end of the module were thematically analysed to determine if and how the activities and sessions had helped to support and develop their entrepreneurial outlooks. Thematic analysis offered a flexible approach to identify reoccurring themes. It provided a top-down perspective to identify and explore how the students' key 
entrepreneurial characteristics were developed through their experience. A total of twenty seven complete reflective essays were used for the thematic analysis. This was supplemented by one-toone feedback from fourteen of the students, as part of the final semester review process. Additional feedback and comments about the module were also collected via the standard university module evaluation process.

\section{Results}

The data collected was thematically analysed using a top down approach, using the four key entrepreneurial characteristics previously identified and discussed earlier for classification. In addition, the student feedback and perceptions of the module were identified and discussed. Each entrepreneurial characteristic is considered in terms of how successful the experiential learning approach was in developing the individual characteristic, what was successful within the experiential learning tasks, and what adjustments could be made to improve the learning from the students' perspective.

\section{Preference for Innovation}

Almost all students reported that they had a better understanding of the importance of innovation and creativity in the business process as a result of completing the module. Some students reported an increased awareness of the benefits that being open to change could provide.

"For the event night, we did not make a profit; I think if we had spent more time being innovative, we could have done better."

"The activities helped me understand the importance of being innovative and better understand what I can do to keep improving myself to be more innovative."

The data highlighted that the tasks in class, wherein students needed to generate innovative business ideas for their enterprises, had helped students understand and appreciate the basis of innovation and how innovative ideas could be constructed. Also, the first enterprise that the students ran (the pop-up shop) had encouraged innovation and making changes "on their feet." The time-bound nature of the task meant that many of the groups had to make changes to their strategies and approaches during the running of their pop-up shop in order to engage different customers: 
"I would have not gone out of my comfort zone this way, if not for the Pop-Up Shop..... I became open to new ways to gain people's attention and became more confident"

Students also reflected that the time-bound pressure of the second enterprise encouraged them to adopt creative and innovative approaches to planning, advertising and running the event:

"Using Facebook to communicate with other group members helped me to be more open to different ways of communicating within a group...... I found I enjoyed it."

"The use of social media to advertise our event was very effective and reduced the loss of time advertising the event."

Students indicated that having to compete with other bars and venues while running their social event forced them to think of innovative ideas in order to offer something different and/or target a different segment in order to make the event a success:

"I felt compelled to come up with ideas that local venues had not already come up with."

"The event night required us to think on our feet and come up with new ideas along the way as we were planning."

Students highlighted that the size of the groups had a limiting impact on innovation; in some cases, students felt embarrassed to present their 'innovative' ideas to the other group members. It was suggested that smaller groups would allow greater involvement of the individual members and would allow for increased participation in the decision making. Although group learning can be beneficial to weaker students by providing peer support to increase their self-esteem and facilitate their learning (Crooks, 1988), certain student groupings may still find it difficult to participate in active engagement. Smaller groups may be more advantageous (Kerr, 1983), although this would require greater organisation and greater funding.

It was also highlighted that activities allowing students to consider existing products/services and discussions of the innovative changes/developments could be introduced to provide examples of different bases of innovation. Looking at SME case studies was also highlighted as a way students 
believed their innovation skills could be improved. This could be introduced as part of the course material either before or during the module.

\section{Proactive Disposition}

The influence of the module on students' proactive disposition was mixed. Some students felt that they were already proactive and the module did little to develop it further. Other students reported that the module made them aware that they needed to be more proactive to be successful at the applied activities. Students reported that:

"This set back in the event has allowed me to reconsider how proactive I actually am."

"I had the opportunities to be proactive but did not take them."

It was widely reported that the two enterprises made students think and plan ahead in order to make the arrangements, order the materials required, and market the events. For example, one group polled their peers to gauge interest in different event night themes to ensure students would be interested in attending. Students also widely reported that working within groups increased their perceived accountability, which increased their proactiveness, as many of the students did not want to let their group down.

Students reported that increased competition between the groups and incentives would have increased the motivation and further encouraged their proactive. This is an interesting point; the creation of specific goals along with a sense of competition can create student engagement with an activity (Ahamer, 2004). Whilst the students were divided into two groups for the second event, competition between the two groups was not actively encouraged. This is an element that could be considered for future such modules.

A reoccurring theme emerged that students felt if they had seen business plans previously produced by other students for similar activities, they would have understood the complexity and expectations of the enterprises. Students felt these examples would have helped them act more proactively. However, the goal of the exercise was to allow the students free reign and not restrict or direct them, instead allowing them to find their own way to apply the taught principles. Entrepreneurial learning involves not only avoiding the mistakes of others and repeating what others have successfully done in the past, but an active interpretation of experience by the learner (Man, 2006). 
It is debateable whether students would learn more with a format to reference or whether this would restrict their ideas and creativity.

\section{Self-Efficacy}

Self-efficacy was the most widely reported entrepreneurial behaviour to be developed through the course of the module. Almost all students reported an increase in entrepreneurial confidence after completing the two enterprises, leading to a sense of achievement and worthiness. An increased confidence in self-promotion was also widely reported upon completion of the module. This came from completing several activities throughout the course of the module, including presenting and pitching ideas, overcoming setbacks and challenges, being part of a group, and developing and running an event from scratch. Comments included:

"At the end of the event my self-efficacy had dramatically increased as I did not believe we would be able to pull of an event as big as this one."

"I took more leadership than I ever have before and that gave me the skills needed to be successful and confident for the event night."

"Presenting individually to my peers is good practice for a future career in business."

Suggestions as to how students' self-efficacy could be improved further were largely based on increased individual accountability. It was suggested that this could have drawn out quieter members of the group, who were at the periphery of the activities. One suggestion was that everyone should present their ideas individually and individual tasks could have been delegated not within the group, but by the instructor. Another suggestion to have the instructor assign group members, rather than allowing the students to choose their own groups. Students believed this would have taken students out of their comfort zones and developed individual self-efficacy. All of these suggestions could easily be incorporated in future modules. Indeed, Oakley et al. (2004) stresses the importance of forming effective groups, as it allows for students to gain improved communication skills and the ability to learn at a deeper level. Hansen (2006) argues that instructor organised groups are more effective than randomized group formations.

Interestingly, the feedback seemed to suggest that self-efficacy was a driver for some of the other dimensions. One example was: 
"Due to the various activities on the module, my confidence has been enhanced and I now have a stronger belief in my ability to complete tasks, demonstrate my abilities and not be afraid to be innovative."

\section{Attitude to Risk Taking}

Many of the students found that their attitude towards risk had changed significantly. It was apparent that many of students had never considered entrepreneurial risk taking and the enterprise activities had helped them to reflect on the benefits of taking calculated risks.

"I am more likely to take risks now..... I now see risk taking as more positive than negative."

"I learnt that risks can bring rewards and they can be calculated to be an asset to an entrepreneur."

"I always thought risk was a bad thing. I am now much more open to take risks as long as I have some base of information that offers less probability of failing."

Organizing and carrying out the events entailed ongoing decision-making, and this was a new experience for many students, particularly those who previously had not been involved in assessing risk and making decisions. A reoccurring theme which came out of the data was that students had an increased realisation that running a business didn't involve taking just one risk, but rather a series of interlinked decisions were required in order to balance risk.

"How to allocate our budget, and what to buy etc. involved a lot of risk but we were able to calculate them so they paid off."

After reflection, students suggested that other activities which might help develop their attitudes and approach to risk included speaking with real life entrepreneurs about the risks they had taken and the risks well-known businesses had taken to get started. It was also suggested that a risk analysis of setting up a business would make students more aware of the practical risks and decisions that would have to be made in the initial set-up of a business post-graduation. Many of these suggestions have previously been discussed in the literature (e.g. Sherman et al., 2008). 


\section{Student Feedback}

Based on student module evaluation, the module received positive module feedback, with $92.9 \%$ of students either strongly agreeing or agreeing that 'they would recommend the module to a friend'. All of the students either strongly agreed or agreed that they 'felt fully engaged with this module'. Positive comments about the experiential learning opportunity that this module provided included:

"I thought having $£ 250$ of cash was an excellent idea as we were actually dealing with real money and not just pound figures on paper. It did make the ideas more real, and deciding what to buy with real money rather than paper or imitation money helped with making business decisions and the figures."

Through the student feedback comments, it was clear that many of the students enjoyed the practical 'hands-on' nature of the module and enjoyed the freedom and creativity that it offered. However, it was also evident that whilst some of the students enjoyed and appreciated the independence the module offered, other students would have preferred more structure and guidance on setting up the enterprises. Some students found the module and assignments were unstructured compared to what they were used to.

In a traditional lecture environment, instructors present concepts in a straightforward manner; however, the aim of the module was to encourage students to take control of their learning (Freeman, 2012), their decisions, and to create a need for them to be proactive while completing tasks. Based on the student reflections, many were happy with the arrangements and felt they rose to the occasion. However, some students found this more challenging, and some suggested they had deliberately sought to benefit from others' work (so-called freeloading). This led some students to suggest that more individual accountability would be useful through individual assessments. Other cited problems included lack of attendance to student arranged meetings, which resulted in delayed decision-making that affected their timelines.

Many of these concerns can be addressed by reducing the size of the groups, although this may involve more organization and have cost implications and may require more of the instructors' resources. Latane's social impact theory (1973), suggests that as group size increases, pressure on the individual diminishes, and the effect of individual non-contribution on the group decreases. Kerr (1983) argued that group size has a direct effect on the motivation of individual group members, with increasing group size contributing to episodes of social loafing, decreasing individual 
motivation. Simon and Hamilton (1994) suggest that a four-member group is optimal, as it will increase an individual's accountability while allowing for adequate division of responsibilities. Davies (2009) mirrored this contention, finding that forming groups of three to four students allowed for better delegation of work and better results. In practice, resources, time, and practicalities may determine the group sizes used.

\section{Conclusion}

Experiential approaches to business and entrepreneurship education have become increasingly popular in recent years and now are often seen alongside more traditional approaches. Approaches are increasingly action-orientated, emphasizing a learning by doing approach (Rasmussen and Sorheim 2006) that can encourage experiential learning by allowing students to actively participate in the entrepreneurial process (Jones and English, 2004). Research suggests that active participation in knowledge creation through group activity or simulation can result in better learning (Frontczak and Kelly, 2000) and furthermore, the challenge of active involvement together with enjoyment of the activity can significantly increase the motivation and learning of students (Elam and Spotts, 2004; Karns, 2005). Entrepreneurship education can thus benefit from experiential learning styles, creative problem solving, and learning by doing in order to engage students (Jones and Iredale, 2010). However, it has been argued that further investigation into the effectiveness and student reactions to experiential approaches is required (Piercy, 2013).

The approach adopted in this project involved a combination of traditional lectures and active participation in group settings to aid learning and develop basic entrepreneurial skills. The aim of this research was to investigate how experiential learning in this applied setting could help in the development of four key entrepreneurial behaviours identified from the literature. The research also sought to identify successful practice and explore how such approaches could be adjusted to improve student learning. Finally, this research sought to measure the level of both student engagement and satisfaction.

Based on the student reflections and student feedback, the experiential learning approach adopted in this research provided an opportunity to develop each of the four entrepreneurial skills. However, the development of self-efficacy was particularly noticeable. The module's requirement to pitch ideas, present findings and reflections, and liaise with members of the wider community seemed to encourage the development of self-efficacy. Overall, as the students developed and enacted their venture ideas, they also developed self-efficacy. It was also interesting to note that the perceptions 
of attitude to risk and innovation had also positively changed in some cases, as in an understanding of the concept of calculated risks and the use of social media as a communication platform. Interestingly, this approach gave students the opportunity to be creative and innovative, for example, through the advertising and promotion of their events. In contrast, the development of a proactive disposition was met with mixed results, with some students believing they were already proactive, and the module had done little to develop it further, whilst for others the module had highlighted that they needed to be more proactive to be successful.

Student feedback indicated a high level of engagement and a high level of student satisfaction. Student suggestions on how to refine the experiential tasks and thus further support the student learning have been considered and discussed in the text. This project has raised several issues that include the consideration of factors such as group size, group formation and the setting of penalties and incentives to make sure all group members are accountable and actively participate. It is worth noting that since some students or cohorts may find the lack of formal structure in this type of approach unsettling, the introduction of some periodic formal deadlines and periodic feedback may be advantageous.

\section{Limitations and Future Research}

In common with other research, this study has limitations. It was based on one group of HND students undertaking one module consisting of two active experiential projects. The experiences of different cohorts undertaking different projects may vary. Although some of the data was collected from critical reflective essays, they were submitted and marked anonymously, which should reduce social desirability bias. Post-course feedback was also collected anonymously.

Future research can investigate different academic levels of cohorts and more complex active experiential projects. New innovative projects can be developed to provide new entrepreneurial insights and challenges to different levels of cohorts. 


\section{References}

Ahamer G (2004) Negotiate your Future: Web-based role play. Campus-Wide Information Systems, 21(1), 35-58.

Aldrich HE and Martinez MA (2007) Many are Called, but Few are Chosen: An Evolutionary Perspective for the Study of Entrepreneurship. In: Cuervo PÁ, Ribeiro PD, and Roig PS (eds), Entrepreneurship, Springer Berlin Heidelberg, pp. 293-311.

Arvanites DA, Glasgow JM, Klingler JW, et al. (2006) Innovation in Entrepreneurship Education. Journal of Entrepreneurship Education, 9, 29-44.

Athayde R (2009) Measuring Enterprise Potential in Young People. Entrepreneurship Theory and Practice, 33(2), 481-500.

Balan P and Metcalfe M (2012) Identifying Teaching Methods that Engage Entrepreneurship Students. Education + Training, 54(5), 368-384.

Begley T and Boyd D (1987) A Comparision of Entrepreneurs and Managers of Small Business Firms. Journal of Management, 13(1), 99-108.

Bevan D and Kipka C (2012) Experiential Learning and Management Education. Journal of Management Development, 31(3), 193-197.

Biggs J (1996) Enhancing teaching through constructive alignment. Higher Education, 32(3), 347364.

Bloom BS, Engelhart MD, Furst EJ, et al. (1956) Taxonomy of educational objectives: The Classification of Educational Goals. New York: David McKay Company.

Bolton DL and Lane MD (2012) Individual Entrepreneurial Orientation: Development of a Measurement Instrument. Education + Training, 54(2/3), 219-233.

Bonwell CC and Eison JA (1991) Active Learning: Creating Excitement in the Classroom. Washington, D.C.: Jossey-Bass.

Caldwell JE (2007) Clickers in the Large Classroom: Current Research and Best-Practice Tips. CBE-Life Sciences Education, 6(1), 9-20.

Carland J, Carland J, Carland J, et al. (1995) Risk Taking Propensity Among Entrepreneurs, Small Business Owners, and Managers. Journal of Business and Entrepreneurship, 7(1), 15-23.

Chen C, Green R and Crick A (1998) Does Entrepreneurial Self-Efficacy Distinguish Entrepreneurs from Managers. Journal of Business Venturing, 13(4), 295-316.

Collins LA, Smith AJ and Hannon PD (2006) Applying a Synergistic Learning Approach in Entrepreneurship Education. Management Learning, 37(3), 335-354. 
Covin JG and Slevin DP (1989) Strategic Management of Small Firms in Hostile and Benign Environments. Strategic Management Journal, 10(1), 75-87.

Crant JM (2000) Proactive Behavior in Organizations. Journal of Management, 26(3), 435-462.

Crooks TJ (1988) The Impact of Classroom Evaluation Practices on Students. Review of Educational Research, 58(4), 438-481.

Daly SP (2001) Student-Operated Internet Businesses: True Experiential Learning in Entrepreneurship and Retail Management. Journal of Marketing Education, 23(3), 204-215.

Davies WM (2009) Groupwork as a Form of Assessment: Common Problems and Recommended Solutions. Higher Education, 58(4), 563-584.

Davis D, Morris M and Allen J (1991) Perceived Environmental Turbulence and Its Effect on Selected Entrepreneurship, Marketing, and Organizational Characteristics in Industrial Firms. Journal of the Academy of Marketing Science, 19(1), 43-51.

Denslow DL and Giunipero LC (2003) Improving Purchasing Success through Entrepreneurial Behaviour. International Supply Management, Nashville, TN: May 18th-21th.

Dewey J (1963) Experience and Education. New York, NY: Collier Books.

Drucker PF (1985) Innovation and Entrepreneurship. New York: Harper \& Row.

Elam ELR and Spotts HE (2004) Achieving Marketing Curriculum Integration: A Live Case Study Approach. Journal of Marketing Education, 26(1), 50-65.

Fayolle A, Gailly B and Lassas-Clerc N (2006) Assessing the Impact of Entrepreneurship Education Programmes: A New Methodology. Journal of European Industrial Training, 30, 701-720.

Feinstein AH, Mann S and Corsun DL (2002) Charting the Experiential Territory: Clarifying Definitions and uses of Computer Simulation, Games, and Role Play. Journal of Management Development, 21(10), 732-744.

Fiet JO (2001) The Pedagogical Side of Entrepreneurship Theory. Journal of Business Venturing, 16(2), 101-117.

Florin J, Karri R and Rossiter N (2007) Fostering Entrepreneurial Drive in Business Education: An Attitudinal Approach. Journal of Management Education, 31(1), 17-42.

Freeman M (2012) To Adopt or not to Adopt Innovation: A Case Study of Team-Based Learning. The International Journal of Management Education, 10(3), 155-168.

Gasse Y (1982) Elaborations on the Psychology of the entrepreneur. In: Sexton D and Kasarda J (eds), The state of the art of entrepreneurship, Boston: PWS-Kent, pp. 57-71.

Gelderen M van, Brand M, Praag M van, et al. (2008) Explaining Entrepreneurial Intentions by Means of the Theory of Planned Behaviour. Career Development International, 13(6), 538-559. 
Gibb A (2002) In Pursuit of a New 'Enterprise' and 'Entrepreneurship' Paradigm for Learning: Creative Destruction, New Values, New Ways of Doing Things and New Combinations of Knowledge. International Journal of Management Reviews, 4(3), 233-269.

Gokhale A (1995) Collaborative Learning Enhances Critical Thinking. Journal of Technology Education, 7(1), 22-30.

Grimley M, Green R, Nilsen T, et al. (2011) Using Computer Games for Instruction: The Student Experience. Active Learning in Higher Education, 12(1), 45-56.

Gundry LK, Ofstein LF and Kickul JR (2014) Seeing Around Corners: How Creativity Skills in Entrepreneurship Education Influence Innovation in Business. The International Journal of Management Education, 12(3), 529-538.

Hansen RS (2006) Benefits and Problems With Student Teams: Suggestions for Improving Team Projects. Journal of Education for Business, 82(1), 11-19.

Harris M, Gibson S and Taylor S (2007) Examining the Impact of Small Business Institute Participation on Entrepreneurial Attitudes. Journal of Small Business Strategy, 18(2), 57-75.

Harris ML and Gibson SG (2008) Examining the Entrepreneurial Attitude of US Business Students. Education + Training, 50(7), 568-581.

Hynes B and Richardson I (2007) Entrepreneurship Education: A Mechanism for Engaging and Exchanging with the Small Business Sector. Education + Training, 49(8/9), 732-744.

Jack SL and Anderson AR (1999) Entrepreneurship Education within the Enterprise Culture: Producing Reflective Practitioners. International Journal of Entrepreneurial Behaviour \& Research, 5(3), 110-125.

Johnson RT and Johnson DW (1986) Action Research: Cooperative Learning in the Science Classroom. Science and Children, 24(2), 31-32.

Jones B and Iredale N (2010) Enterprise Education as Pedagogy. Education + Training, 52(1), 7-19.

Jones C and English J (2004) A Contemporary Approach to Entrepreneurship Education. Education + Training, 46(8/9), 416-423.

Karlsson T and Moberg K (2013) Improving Perceived Entrepreneurial Abilities through Education: Exploratory Testing of an Entrepreneurial Self Efficacy Scale in a Pre-post Setting. The International Journal of Management Education, 11(1), 1-11.

Karns GL (2005) An Update of Marketing Student Perceptions of Learning Activities: Structure, Preferences, and Effectiveness. Journal of Marketing Education, 27(2), 163-171.

Kelley CA (2000) The Editor's Corner. Journal of Marketing Education, 22(2), 83-83.

Kerr NL (1983) Motivation Losses in Small Groups: A Social Dilemma Analysis. Journal of Personality and Social Psychology, 45(4), 819-828. 
Knight JK and Wood WB (2005) Teaching More by Lecturing Less. Cell Biology Education, 4(4), 298310.

Knight PT and Yorke M (2003) Employability and Good Learning in Higher Education. Teaching in Higher Education, 8(1), 3-16.

Kolb A and Kolb D (2009) Experiential Learning Theory: A Dynamic Holistic Approach to Management Learning, Education and Development. In: Armstrong SJ and Fukami C (eds), Handbook of Management Learning, Education and Development, London: Sage Publications, pp. 42-68.

Kolb D (1984) Experiential Learning. Englewood Cliffs, NJ: Prentice Hall.

Krueger Jr. NF (2000) The Cognitive Infrastructure of Opportunity Emergence. Entrepreneurship Theory \& Practice, 24(3), 9-27.

Kumar M (2007) Explaining Entrepreneurial Success: A Conceptual Model. Academy of Entrepreneurship Journal, 15(1), 57-77.

Kuratko DF (2005) The Emergence of Entrepreneurship Education: Development, Trends, and Challenges. Entrepreneurship Theory \& Practice, 29(5), 577-597.

Latane B (1973) A Theory of Social Impact. St, Louis, Mo.: Psychonomic Society.

Lean J, Moizer J, Towler M, et al. (2006) Simulations and Games Use and Barriers in Higher Education. Active Learning in Higher Education, 7(3), 227-242.

Louw L, Eeden SM van, Bosch JK, et al. (2003) Entrepreneurial Traits of Undergraduate Students at Selected South African Tertiary Institutions. International Journal of Entrepreneurial Behaviour \& Research, 9(1), 5-26.

Lumpkin GT and Dess GG (1996) Clarifying the Entrepreneurial Orientation Construct and Linking It To Performance. Academy of Management Review, 21(1), 135-172.

Lumpkin GT and Dess GG (2001) Linking Two Dimensions of Entrepreneurial Orientation to Firm Performance: The Moderating Role of the Environment and Industry Life Cycle. Journal of Business Venturing, 16(5), 429-451.

Mahajan A (2012) An Experiential Approach to Developing a Pay Structure: Insights from Teaching Compensation Management. The International Journal of Management Education, 10(1), 2-11.

Makienko I and Bernard EK (2012) Teaching Applied Value of Marketing Research: A Questionnaire Design Project. The International Journal of Management Education, 10(2), 139-145.

Man TWY (2006) Exploring the Behavioural Patterns of Entrepreneurial Learning: A Competency Approach. Education + Training, 48(5), 309-321.

Masters R and Meier R (1988) Sex Differences and Risk-taking Propensity of Entrepreneurs. Journal of Small Business Management, 26(1), 31-35. 
Mezirow J (1990) Fostering Critical Reflection in Adulthood. San Francisco: CA: Jossey-Bass.

Miller D (1983) The Correlates of Entrepreneurship in Three Types of Firms. Management Science, 29(7), 770-791.

Naman JL and Slevin DP (1993) Entrepreneurship and the Concept of Fit: A Model and Empirical Tests. Strategic Management Journal, 14(2), 137-153.

Oakley B, Brent R, Felder RM, et al. (2004) Turning Student Groups into Effective Teams. Journal of Student Centered Learning, 2(1), 9-34.

Oosterbeek H, van Praag M and ljsselstein A (2010) The Impact of Entrepreneurship Education on Entrepreneurship Skills and Motivation. European Economic Review, 54(3), 442-454.

Ormrod JE (2008) Human Learning. Upper Saddle River, N.J.: Pearson.

Patel NV (2003) A Holistic Approach to Learning and Teaching Interaction: Factors in the Development of Critical Learners. The International Journal of Educational Management, 17(6), 272284.

Piaget J (1950) The Psychology of Intelligence. London: Routledge.

Piercy N (2013) Evaluating Experiential Learning in the Business Context: Contributions to Groupbased and Cross-functional Working. Innovations in Education and Teaching International, 50(2), 202-213.

Piercy N and Caldwell N (2011) Experiential Learning in the International Classroom: Supporting Learning Effectiveness and Integration. The International Journal of Management Education, 9(2), $25-35$.

de Pillis E and Reardon KK (2007) The Influence of Personality Traits and Persuasive Messages on Entrepreneurial Intention: A Cross-cultural Comparison. Career Development International, 12(4), 382-396.

Platzer H, Snelling J and Blake D (1997) Promoting Reflective Practitioners in Nursing: A Review of Theoretical Models and Research into the Use of Diaries and Journals to Facilitate Reflection. Teaching in Higher Education, 2(2), 103-121.

Prince M (2004) Does Active Learning Work? A Review of the Research. Journal of Engineering Education, 93(3), 223-231.

Pruett M, Shinnar R, Toney B, et al. (2009) Explaining Entrepreneurial Intentions of University Students: A Cross-cultural Study. International Journal of Entrepreneurial Behaviour \& Research, 15(6), 571-594.

Rasmussen EA and Sørheim R (2006) Action-based Entrepreneurship Education. Technovation, 26(2), 185-194. 
Rauch A, Wiklund J, Lumpkin G t., et al. (2009) Entrepreneurial Orientation and Business Performance: An Assessment of Past Research and Suggestions for the Future. Entrepreneurship Theory and Practice, 33(3), 761-787.

Rhem J (1998) Problem-Based Learning: An Introduction. The National Teaching \& Learning Forum, $8(1), 1-4$.

Robinson PB, Stimpson DV, Huefner JC, et al. (1991) An Attitude Approach to the Prediction of Entrepreneurship. Entrepreneurship Theory \& Practice, 15(4), 13-30.

Ross S (2011) Focused Active Learning to Improve Organizational Performance. International Journal of Management Education, 9(4), 39-49.

Ruben BD (1999) Simulations, Games, and Experience-Based Learning: The Quest for a New Paradigm for Teaching and Learning. Simulation \& Gaming, 30(4), 498-505.

Schumpeter JA (1942) Capitalism Socialism and Democracy. London: Allen \& Unwin.

Sesen H (2013) Personality or environment? A comprehensive study on the entrepreneurial intentions of university students. Education + Training, 55(7), 624-640.

Shane S, Locke EA and Collins CJ (2003) Entrepreneurial Motivation. Human Resource Management Review, 13(2), 257-279.

Sherman PS, Sebora T and Digman LA (2008) Experiential Entrepreneurship in the Classroom: Effects of Teaching Methods on Entrepreneurial Career Choice Intentions. Journal of Entrepreneurship Education, 11, 29-42.

Simon B and Hamilton DL (1994) Self-stereotyping and Social Context: The Effects of Relative Ingroup Size and In-group Status. Journal of Personality and Social Psychology, 66(4), 699-711.

Snyder KD (2003) Ropes, Poles, and Space Active Learning in Business Education. Active Learning in Higher Education, 4(2), 159-167.

Solomon G (2008) Entrepreneurship Education in the United States. In: Potter J (ed.), Entrepreneurship and Higher Education, Paris: OECD and LEED, pp. 95-118.

Stewart WH and Roth PL (2004) Data Quality Affects Meta-analytic Conclusions: A Response to Miner and Raju (2004) Concerning Entrepreneurial Risk Propensity. The Journal of Applied Psychology, 89(1), 14-21.

Stewart WH, Watson WE, Carland JC, Carland JW (1999) A Proclivity for Entrepreneurship: A Comparison of Entrepreneurs, Small Business Owners, and Corporate Managers. Journal of Business Venturing, 14(2), 189-214.

Taatila V and Down S (2012) Measuring entrepreneurial orientation of university students. Education + Training, 54(8/9), 744-760. 
Tang JT, Tang Z, Marino LD, et al. (2008) Exploring an inverted U-shape relationship between entrepreneurial orientation and performance in Chinese ventures. Entrepreneurship Theory and Practice, 32(1), 219-239.

Timmons J., Gillin LM, Burshtein SL, et al. (2011) New Venture Creation: Entrepreneurship for the 21st Century: A Pacific Rim Perspective. Sydney: McGraw-Hill.

Tsay M and Brady M (2012) A Case Study of Cooperative Learning and Communication Pedagogy: Does Working in Teams Make a Difference? Journal of the Scholarship of Teaching and Learning, 10(2), 78-89.

Van der Sijde P, Ridder A, Blaauw G, et al. (2008) Teaching Entrepreneurship: Cases for Education and Training. Heidelberg: Physica-Verlag.

Von Graevenitz G, Harhoff D and Weber R (2010) The Effects of Entrepreneurship Education. Journal of Economic Behavior \& Organization, Special Issue: Experimental Methods in Entrepreneurship Research, 76(1), 90-112.

Wiklund J (1999) The Sustainability of the Entrepreneurial Orientation Performance Relationship. Entrepreneurship Theory and Practice, 24, 37-48.

Wilson K (2008) Entrepreneurship Education in Europe. In: Potter J (ed.), Entrepreneurship and Higher Education, Paris: OECD and LEED, pp. 119-138.

Zahra SA and Welter F (2008) Entrepreneurship Education for Central, Eastern and Southeastern Europe. In: Potter J (ed.), Entrepreneurship and Higher Education, Paris: OECD and LEED, pp. 165192.

Zhao H, Seibert SE and Hills GE (2005) The Mediating Role of Self-Efficacy in the Development of Entrepreneurial Intentions. Journal of Applied Psychology, 90(6), 1265-1272.

\section{Acknowledgments}

This research was kindly supported by an Academy of Marketing, Teaching and Research Development Grant (2013/14). 